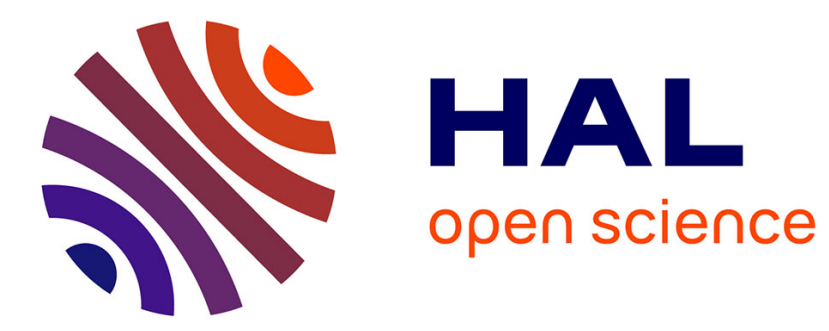

\title{
The entry of China to the gas market: constraints and opportunities
}

\author{
Catherine Locatelli
}

\section{To cite this version:}

Catherine Locatelli. The entry of China to the gas market: constraints and opportunities. International Journal of Global Energy Issues, 2004, 22 (2/3/4), pp.119-130. halshs-00002742

\section{HAL Id: halshs-00002742 \\ https://shs.hal.science/halshs-00002742}

Submitted on 1 Sep 2004

HAL is a multi-disciplinary open access archive for the deposit and dissemination of scientific research documents, whether they are published or not. The documents may come from teaching and research institutions in France or abroad, or from public or private research centers.
L'archive ouverte pluridisciplinaire HAL, est destinée au dépôt et à la diffusion de documents scientifiques de niveau recherche, publiés ou non, émanant des établissements d'enseignement et de recherche français ou étrangers, des laboratoires publics ou privés. 


\title{
The entry of China to the gas market: constraints and opportunities
}

\author{
Catherine Locatelli \\ Research Fellow, CNRS \\ LEPII-EPE (formerly IEPE), University of Grenoble II, December 2003 \\ Submitted to International Journal of Global Energy issues
}

\begin{abstract}
China will emerge in the next twenty years as a major importer of gas and thus shape the energy exchanges and markets in Asia. But different constraints must be overcome. The increase of natural gas share in the Chinese energy balance will depend on the country's capacity to create a unified gas market in place and instead of the fragmented exchanges. This implies several economic and institutional reforms (as for example the energy price reform). One important element that will determine the growth of the Chinese gas industry concerns the role of international investors.

The growth of the Chinese gas demand would lead to a radical change in the country's energy policy, which up until now has been dominated by the search for self-sufficiency. From this point of view, the question of the choices of the main gas suppliers is essential concerning the Chinese energy security. Different countries are in competition. But the choices of the main suppliers are very linked with the way in which China perceives its integration at the international level and in the Asian region.
\end{abstract}

\section{Key words}

Chinese gas demand, Chinese gas price reform, International investments, gas pipeline projects, GNL projects, Energy security, Russia, Caspian countries. 
In the next twenty years, it is expected that China will emerge as a major importer of gas and thus shape the energy exchanges and markets in Asia for several decades to come. The environmental constraints that it is facing, with its current energy needs being predominantly satisfied by coal, mean that it will have to turn over to natural gas on a huge scale. This will create a huge change in Chinese energy balance. Bringing the share held by gas to $10 \%$ of energy requirements in 2020 (compared with a mere $2 \%$ today) will involve choices and changes that will move beyond the scope of energy alone and have an effect on economic development, economic and institutional reform and international integration.

The increase of natural gas share in the Chinese energy balance will depend on the country's capacity to create a unified gas market in place and instead of the fragmented exchanges mostly guided by mechanisms that are the product of planned economy practices. Two main constraints need to be taken into account. On one hand, the lack of transportation and distribution structures leads to the creation of markets that are essentially regional, whose structure is reinforced by specific organisation of some enterprises into networks. In a country such as China, in view of the location of the production centres (which may in future become import centres) and of that of the consumption centres, transportation is a determining variable in the creation of a unified market. On the other hand, the price and competitiveness of natural gas, especially in relation to coal, is of paramount importance. A consistent reform of the whole of the price formation system, a legacy of the planned economy, is essential to ensure the entry of gas into the Chinese market. It is however being held back by issues of social acceptability, industrial policy, employment and development choices, and all these issues have led to the creation of many different price systems and therefore to significant distortions.

The second element that will determine the growth of the Chinese gas industry concerns the role of international investors. The development patterns envisaged imply that there will be considerable investment, and it should be assumed that China will not be able to finance the whole of this investment in such a short period. Although economic growth in China has largely been facilitated by foreign investment, the energy industry has largely been by-passed by these developments because of the government's wish to maintain strict control over this strategic sector. The opening of an upstream and downstream gas sector must undergo changes to its legal and fiscal situation in order to attract investors in a sector that is highly capitalistic and carries significant risks. The main stake of this international finance relates to the place that the State is anticipating granting to the international oil companies in energy developments of the country. Sinopec, Petrochina and CNOOC, considered by the State to be the key companies, remain largely under State control despite the process of "corporatisation", and thus benefit from a number of advantages that tend to slow down the penetration of foreign capital.

Finally there is the issue of self-sufficiency, linked to that of energy safety, which will be a determining variable as it conditions both levels of importation and possible supplier choices at the same time. The question that needs to be answered is whether the government will allow importation by gas pipeline or future LNG imports in competition with national production. Another question concerns the choice of suppliers and the way in which China perceives its integration at international level and in the Asian region.

\section{I - CONSTRAINTS ON THE EMERGENCE OF GAS INTO CHINA}


In the next ten years, it is likely that the Asian region will emerge as a major gas zone with demand that is likely to rise from $274 \mathrm{bcm}$ (billion of cubic meters), in 2002 to over $350 \mathrm{bcm}$ in 2010 and may reach or even exceed $500 \mathrm{bcm}$ by $2020^{1}$. The stakes, therefore, are considerable. The Asian gas consumption is dominated by the four "giants" Japan, China, India and South Korea. It is however mostly the needs of China and India that will lead to the increased demand, while Japan and South Korea, where gas already plays a significant role in the energy balance sheet (over $12 \%$ in Japan in 2002) should see a slightly slower growth in their gas demand. Thus, between 2010 and 2020, China could make a contribution of about $34 \%$ to increases in demand for gas in Asia, while India's contribution will be in the region of $20 \%$ (compared with only 3\% for Japan and 8\% for South Korea ${ }^{2}$ ).

\subsection{Gas demand in China}

During the next twenty years, gas balances and exchanges throughout this area will depend to a considerable extent on the Chinese energy situation. According to the scenarios considered, it is reckoned that between 2000 and 2020 demands for gas in China will increase (at a rate that is not just considerable but unprecedented) by $10 \%$ per year. Officially, the government's aim is to increase the role played by natural gas in energy supplies, from $2.5 \%$ in 2000 to $6 \%$ in 2010 and $10 \%$ in $2020^{3}$. There is however a great deal of uncertainty as according to the scenarios, Chinese gas demand varies between $60 \mathrm{bcm}$ and $120 \mathrm{bcm}$ in 2010 (that is, double) and between 109 and $200 \mathrm{bcm}$ at the 2020 horizon (Table 1). In 2020, therefore, Chinese importations could be anywhere between 28 and $100 \mathrm{bcm}$; this will have a major influence on problems of gas exchanges in Asia ${ }^{4}$.

Table 1: Various forecast scenarios for gas demands in China, in bcm

\begin{tabular}{|l|c|c|c|c|}
\hline & $\mathbf{2 0 0 5}$ & $\mathbf{2 0 1 0}$ & $\mathbf{2 0 1 5}$ & $\mathbf{2 0 2 0}$ \\
\hline PetroChina & 63.7 & 106.8 & 153.4 & 210.7 \\
\hline ERI/SDPC & 64.5 & 120.0 & 160.0 & 200.0 \\
\hline BP & 42.0 & 74.0 & 135.0 & 177.0 \\
\hline CNOOC X. & 61.0 & 100.0 & 150.0 & 200.0 \\
\hline $\begin{array}{l}\text { D. Xiucheng, J9-66 } \\
\text { Logan }\end{array}$ & & $81-110$ & $126-170$ & 126.0 \\
\hline EIA/DOE 2003 & 51.0 & 64.4 & 106.4 & 137.5 \\
\hline APEC & & 68.8 & - & 109.0 \\
\hline AIE, WEO2002 & & $70-105$ & - & $120-200$ \\
\hline $\begin{array}{l}\text { Oxford Energy } \\
\text { Studies 2002 }\end{array}$ & & & - & 20.0 \\
\hline $\begin{array}{l}\text { Royal Institute of } \\
\text { International Affairs }\end{array}$ & & & & - \\
\hline
\end{tabular}

Sources : Developing China's Natural Gas Market : The Energy Policy Challenges.- AIE-OCDE, 2002, p. 67 ;

\footnotetext{
${ }^{1}$ According to APEC forecasts, demands for gas in Asia will reach 359 bcm by 2010 and 537 bcm by 2020 . According to EIA-US DOE, it will reach $370 \mathrm{bcm}$ of gas by 2010 and $552 \mathrm{bcm}$ by 2020 .

${ }^{2}$ These calculations are based on the Asian gas demand scenario produced by EIA-US DOE, 2003.

${ }^{3}$ « Modernizing China's Oil and Gas Sector : Structure Reform and Regulation ».- Consolidated Joint Report of The World Bank and the Institute of Economic System and Management, 20 november 2000, $51 \mathrm{p}$.

${ }^{4}$ These levels of importation also depend of the levels reached by China's internal production. The Chinese are anticipating producing $83 \mathrm{bcm}$ in 2010 and $110 \mathrm{bcm}$ in 2020. Developing China's Natural Gas Market: The Energy Policy Challenges, AIE-OCDE, 2002, p. 78.
} 
Xiucheng (D.), Logan (J.).-Expanding Natural Gas in China.- Advanced International Studies Unit, Pacific Northwest National laboratory, 2002, p. 57 ; Fridley (D.).- « Chapter 3 : Natural Gas in China” in Wybrew-Bond (I.), Stern (J.), eds.- Natural Gas in Asia : The Challenges of Growth in China, India, Japan and Korea.- Oxford Institute for Energy Studies, 2002, p. 5-65.

\subsection{The need to create a real market for gas}

The differences observed in relation to gas demand at the 2010-2020 horizon, according to different scenarios envisaged, show the serious constraints currently weighing on the emergence of gas in China. These constraints must be lifted if the government is to reach its targets. They relate to issues of competitiveness of gas in relation to other energy sources, to questions of prices and gas supply costs, and to China's capacity to create, at the desired pace, a transport system and distribution network that is compatible with these levels of consumption. If the network is not sufficiently developed, gas will be predominantly consumed in the place where it is produced ${ }^{5}$. The investment required will be considerable and indeed cannot be envisaged without the definition of a true gas policy that is able to answer the key question: what are the incentives for allowing the rapid (10-20 years) and large-scale development of an industry that is currently in its infancy and still bears to a considerable extent the mark of the planned economy? Answering this question involves making major political and organisational changes, especially with regard to levels of control and State intervention, and with regard to the level of deregulation and the structure of the energy industries.

\section{- The competitiveness of gas compared with coal at final consumption level}

The Chinese industrial sector is the main consumer of gas, most notably for the production of fertiliser. In future, however, increases in demand for gas should mostly be brought about by the power and residential sectors ${ }^{6}$. In these two sectors, the economic conditions required to allow a strong demand for gas to emerge are not being fulfilled. In fact, in the areas of use in which the two energy sources are in competition, competitiveness of gas in relation to coal is not assured. For example, the price of a $\mathrm{kWh}$ produced by gas is over 0.45 yuan, compared with less than 0.35 yuan per $\mathrm{kWh}$ for coal ${ }^{7}$. This situation can be explained by a number of factors, most notably the pricing policy currently pursued by the government. The strategy of self-sufficiency for energy, adopted by China, has systematically favoured the development of coal on the basis of an incentive price policy and separate, independent prices for each energy type. This situation is exacerbated by very low electricity prices, which are not conducive to the emergence of gas. This reflects the practices and distortions of the planned economy and the method of industrialisation currently being applied. In consequence, the power industry reform is without doubt a major prerequisite for gas to emerge. More generally, it is important that the Chinese government will quickly set up the economic incentives needed for the consequent demand for gas to emerge . $^{8}$

\footnotetext{
${ }^{5}$ Xiucheng (D.), Logan (J.).- Expanding Natural Gas Use in China.- Advanced International Studies Unit, april 2002, p. 52.

${ }^{6}$ Gas may account for $12 \%$ of Chinese power production in 2010 and $14 \%$ in 2020.

${ }^{7}$ The cost of supplying gas would be 1.39 yuan per cubic meter. In Loi Lei Lai, 2003, op. cit., p. 8.

${ }^{8}$ According to AIE, if the environmental cost is excluded, the use of coal is more economical in industry with just a few exceptions (such as the ceramics industry), in residential consumption and in power production.
} 


\section{- Incentives and price reforms in relation to supply}

In addition to the barriers to the emergence of gas at final demand level, there is a lack of incentive to develop gas supply. What is needed today is the creation of a true gas market, characterised by contractual relations in place of the physical relations produced by the planned economy. In fact, the organisational logic of the Chinese gas market is based primarily on a system of resource allocation, based in turn on quotas accompanied by an administered price system. These two mechanisms of volume allocation and administered prices, limit the profitability of the actors in the gas sector and do not encourage new entrants, especially international investors.

Two price systems are currently in force. The traditional system, for the gas projects commissioned before 1995, is a two-level system (two tier market) established on the basis of quotas regulated by a production plan. Volumes of gas are allocated to certain categories of consumers on the basis of administered prices set at very low levels. These prices constitute the "quota prices"9. Through this system, the fertiliser industry receive annual gas allocations (as a priority) and thus benefits from gas supplies at prices that can sometimes be noticeably lower than production costs. The higher percentage of this type of gas allocations given to industry in comparison with other sectors is indicative of the Chinese government's priorities in relation to industrialisation and agricultural development ${ }^{10}$. Defining these prices is primarily the responsibility of the State Development Planning Commission, or SDPC, which has not altered them since $1997^{11}$. Beyond these quotas, production may be sold freely, but the price must be established within a corridor of $10 \%$ more or less compared to the prices established by the SDPC.

The "new system" set up in 1995 for gas projects developed after 1997 establishes a contract price freely negotiated between producer and consumer. The contract price is, however, still subject to SDPC approval. We therefore have a system of multiple and complex prices, which makes the creation of a unified gas market very difficult. The regional dimension is also in evidence and tends to further the fragmentation already present in the market. Some regions, in fact, have been able to negotiate specific price mechanisms with the central institutions ${ }^{12}$. The allocation of gas resources by volumes is complemented by a system of import and export licences, which acts as a further barrier to the creation of real energy markets.

The new price system is a first step towards deregulation of natural gas prices in China, even though at present it only applies in very restricted sectors of the market. It appears to be an effort to take account more effectively of all the production costs, and in that respect it may

\footnotetext{
${ }^{9}$ For a detailed analysis of Chinese price structures, reference may be made to Chapter 6 of Natural Gas Pricing and Taxation, AIE/OCDE, 2002, op. cit., p. 177-206.

${ }^{10}$ Fridley (D.).- « Chapter 3 : Natural Gas in China" in Wybrew-Bond (I.), Stern (J.), eds.- Natural Gas in Asia : The Challenges of Growth in China, India, Japan and Korea.- Oxford Institute for Energy Studies, 2002, p. 5-65.

11 During September 2003 this commission was renamed: State Development and Reform Commission. « China's government Restructuring Plan Adopted ».- People's Daily, 22 september 2003.

${ }^{12}$ Fuqiang (Y.), Duan (N.), Huan (Z.), Leerne (M.), Martin (N.), Sinton (J.), Zhou (F.), Zhue (C.).- A Review of China's Energy Policy.- Lawrence Berkeley Laboratory Report, LBL-35336, 1995, p. 28.
} 
have a positive effect. At the same time, however, it bears witness to the difficulty of deregulating energy prices totally given that the social and therefore the political stakes are so high for the government. Given these issues, it is hardly surprising that the government is attempting, by means of complex mechanisms, to keep the price formation system largely under its control, even in the context of the new system in which efforts have been made to develop, in certain sectors, prices guided by supply and demand. In this context the State, as a last resort, is maintaining strict control over the formation of gas prices and as such remains the final decision-maker.

The reform of gas prices is an essential condition for large-scale development of the Chinese gas market, in terms of supply as well as demand. However, it should resolve the major contradiction between prices that do not seem to be sufficiently lucrative at supply level to make the required investment profitable ${ }^{13}$ and are at the same time too high (especially in relation to coal) to make large-scale emergence of gas in the residential and power production sectors feasible. What is at stake, therefore, is a global and coherent reform of energy prices, with the introduction of new relative prices between energy forms. In particular, this supposes to define "the replacement value of gas in comparison with alternative energy forms" $"$. From this viewpoint, a partial price reform is not sufficient.

\section{- The question of international investments}

The development of the Chinese gas industry, in view of the volumes involved and the relatively short time period needed to create such an industry, will require major investment, especially in the transport and distribution infrastructures. This kind of investment simply cannot be envisaged without very significant recourse to international investors. The "WestEast" gas pipeline project, which should link the deposits in the Tarim Basin in Xinjiang and those in the Ordos basin in Shaanxi with the consumer areas in Eastern China (Shanghai and the Yangtze delta) ${ }^{15}$ is a specific illustration of this. It will be implemented by a joint venture consisting of two Chinese companies (Petrochina 50\% and Sinopec 5\%) and an international consortium (Shell and Hong Kong China Gas 15\%; Gazprom and Stroytransgaz 15\%; Exxon Mobil and Hong Kong China Light and Power 15\%) ${ }^{16}$. Representing one of the first major undertakings by investors in gas in China, this project is a test of first importance in terms of the government's willingness to promote the development of this energy and of the structural problems that will face the foreign investors. In this matter, the concerns and interests of the various actors involved will not be of the same kind ${ }^{17}$.

The Chinese economic, legislative and institutional environment is still not sufficiently attractive. The uncertainty over the increase in Chinese gas demand has posed a serious

\footnotetext{
${ }^{13}$ According to the study by the Beijing University of Petroleum and the Pacific Northwest National Laboratory, the average well-head price of gas would be about 0.65 yuan per cubic meter. D. Xiucheng, J. Logan, 2002, op. cit., p. 23.

${ }^{14}$ AIE/OCDE, 2002, op. cit., p. 189.

15 «Gazprom, Shell, Hong Kong China Gas Co and Stroitransgaz team up for West-East pipeline ».- Gas Briefing International, october 2001, p. 10.

${ }^{16}$ AIE, 2002, p. 217.

${ }^{17}$ Rather than being an energy stake, one of the major benefits of this project, in the Chinese government's eyes, is that it will allow the social and economic development of deprived areas. D. Fridley, 2002, op. cit., p. 14.
} 
barrier to large-scale international investment, especially in the long-distance pipeline network. The European experience is exemplary in this sense and shows the importance of securing outlets when faced with a need to create a long-distance pipeline network. In this sense, the risk currently being run by the international oil companies is significant, as several projects have been started without the benefit of secured outlets in return. The same also applies to the "West-East" pipeline project as well as to several other LNG projects ${ }^{18}$. Beyond the pilot experiments, the generalisation of such investments would suggest that the question of prices, already touched on, has been resolved.

The resulting international investments in the Chinese energy sector raise a fundamental question in relation to the State's willingness to lessen its financing and therefore its control of the sector. Although in other sectors China has clearly chosen a method of development based on international investments, the choice is not so easy in the field of energy, which has a clearly advertised policy in favour of self-sufficiency of energy. In some areas, international oil companies continue to be confronted with policies that greatly restrict their participation in Chinese energy markets. Current regulations in the matter of marketing of gas, participation by international investors in infrastructures, or access to hydrocarbon resources, bear witness to this ${ }^{19}$. On one hand, international investors are being confronted with very restrictive regulations in the matter of downstream gas sales. Production obtained in the context of a product sharing agreement concluded with international investors can only be marketed by national (State-held) companies or by joint ventures created with national companies. This will not encourage international oil companies to invest either in Chinese deposits or in the infrastructures, even though they have been recently authorised to do so. On the other hand, the insufficiently developed legal framework tends to favour the national companies to the detriment of foreign investors, especially in relation to the procedures for granting exploration and development licences. The role given to the local authorities in this process increases the risk run by the international companies.

Finally, the discretionary risk faced by foreign investors is greatly increased because of the lack of a clear definition of the roles played by the energy companies and by the State. This leads to a confusion of powers and lack of transparency in the decision-making process, because of the very large number of actors at both national and regional level ${ }^{20}$. Despite the reforms of 1998 and 1999 aimed at separating the State from the national companies ${ }^{21}$, these

\footnotetext{
${ }^{18}$.« Faith, not Fact, drives China Gas ».- PIW, 4 august 2003, p. 3.

${ }^{19}$ D. Fridley, 2002, op. cit., p. 26.

${ }^{20}$ The Ministry of Energy was abolished in China in 1992. The various responsibilities for the sector are now divided between:

- The State Economic and Trade Commission, which holds the functions previously held by the Ministers for Electricity and Coal and the functions for regulating the three national hydrocarbon companies.

- The State Development Planning Commission, which lays down and regulates energy prices, defines medium and long-term energy plans, and approves energy projects on the basis that major investments will be made.

- The Ministry of Land and Natural Resources, which issues exploration and development licences, approves concessions issued to international investors, and evaluates reserves.
}

AIE/OCDE, 2002, op. cit., p. 293-297.

${ }^{21}$ In 1998, the two main State oil and gas companies, CNPC (China National Petroleum Corporation) and Sinopec (China Petroleum Corporation) were converted into joint-stock companies under a "corporatisation" process traditional in former planned economies. They were also reorganised, on a regional basis, into two vertically integrated companies. CNPC predominates in the North and West and Sinopec in the South. China National Offshore Company (CNOOC) holds most of the offshore hydrocarbon production. There is therefore a 
companies have preserved energy and regulation policies that should really devolve on the State. This situation has led to many conflicts of interest and discriminatory practices in relation to international oil companies. For example, the State energy companies continue to play an active part in the approval of foreign investments.

\section{II - THE SOURCES OF SUPPLY: LNG VERSUS GAS PIPELINES}

A number of projects for supplying gas to China can be envisaged; they would be based on a number of central questions. On one hand, they relate to the choice to be made between a supply based principally on LNG or a supply based principally on natural gas transported along long-distance pipelines. On the other hand, they relate to the choice of supplier country. The hypotheses that can be postulated on level of gas demand, and the search of a balance between national supplies and imports, are determining variables in the arbitrage process to be conducted between the pipeline option and the LNG option. These choices are not mutually exclusive. However, the competitiveness of transportation of gas along pipelines over 4,000 $\mathrm{km}$ long (in the best situation) cannot be envisaged unless there are sufficient quantities to import. In consequence, in view of the uncertainty relative to Chinese gas demand, the LNG option appears more realistic in the short term.

The question of "pipelines versus LNG" overlaps partly with the question of choice of principal supplier, the second major issue currently confronting China. The economic variables must be taken into consideration. But, they interfere with the issues relating to the energy security expressed in China's asserted willingness to diversify its suppliers. A policy of mass gas importation would lead to a radical change in the country's energy policy, which up until now has been dominated by the search for self-sufficiency based on strategies for increasing energy production regardless of $\cos ^{22}$. The way in which China will attempt to face the new stakes in the security of its supplies will be the determining factor in the choices that it makes. Diversification of its suppliers is an initial response (and no doubt will be insufficient in the Chinese government's eyes). A policy of investment in deposits in producer countries, through internationalisation of its oil companies, is a second response. As well as the economic issues and the problem of energy security, the choices will also be conditioned by the international strategy for integration, especially in Asia, that the country intends to follow in future years. Its closeness to Russia and Central Asian countries such as Kazakhstan and Turkmenistan is partially based on energy (as indeed is its current opposition to Japan ${ }^{23}$ ). From this point of view, China has also strategic interests in the Middle East as a whole.

\subsection{The emergence of a "gas pipeline network" in Asia?}

In the matter of gas pipelines, two major options can be envisaged, with degrees of feasibility that are highly variable over time. However, we are looking overall at long-term projects only

situation of regional quasi-monopolies, which limits the introduction of competition into the Chinese hydrocarbons sector.

${ }_{22}^{22}$ Philip Andrews-Speed tries to divine China’s future energy policy »-- Oxford Energy Forum, may 2003, p.57.

${ }^{23}$ China and Japan are currently opposed over the first Russian crude oil export pipeline aimed at Asia. Japan is militating in favour of the option passing through Nakhodka, on the Pacific Coast, which would give priority to supplying Japan, while China is weighing heavily in favour of giving priority to the Angarsk-Daqing-Beijing line. As yet, Russia has not made a decision. 
(after 2015) because of the financial commitments required and the uncertainty over Chinese demand. One of these options concerns Russia, with a number of different versions. The other relates to the Caspian and Central Asian territories, principally Kazakhstan and Turkmenistan. The "Russia and Central Asia" zone is becoming more and more credible as a supply area for Asia and more specifically China. The reserves identified, although still uncertain, would generally be sufficient to make the setting-up of a transcontinental gas pipeline network system tenable. However, a number of constraints will have to be lifted before such projects can be realised. The first of these, as we have already mentioned, is that of the profitability of the infrastructures in the light of the financial commitments required. The second relates to the risk associated with such investments. This risk is significantly increased by the economic, political, institutional and legal instability in the countries of this area, caused by a difficult and disorganised transition process. All these factors are likely to limit the essential involvement of the international oil companies in the development of reserves in these countries. At the same time, the question of political and economic stability of the different transit countries, essential for transcontinental gas pipelines, may be of great importance and weigh heavily on the profitability of the projects envisaged by significantly increasing the financial risk linked to very specific investments.

\section{- The Russian option}

The Russian option consists of supplying China through the development of the new and as yet little exploited production area in Eastern Siberia, even though schemes based on the deposits in Western Siberia are already envisaged ${ }^{24}$. This is an integral part of the creation of a "Northeast Asia Gas Pipeline Network", the aim of which is to link Japan, China and Korea to the productive areas in Sakhalin and Eastern Siberia; in this system, China would play a central role ${ }^{25}$. Three major areas of reserves can be identified in Eastern Siberia: that of the Sakha Republic, that of the Irkutsk and Krasnoyarsk Regions, and that of Sakhalin. In these three zones, the proven and potential reserves of hydrocarbons are far from insignificant as they are assessed at between $3,700 \mathrm{bcm}$ and 5,300 bcm according to sources for the proven reserves, and at over $50,000 \mathrm{bcm}$ for total reserves ${ }^{26}$. According to Russia's long-term energy plan, these reserves allow production of between 25-30 bcm (conservative scenario) and 50 $\mathrm{bcm}$ (optimistic scenario) to be envisaged in 2010 and production of between $55-90 \mathrm{bcm}$ (conservative scenario) and $110 \mathrm{bcm}$ (optimistic scenario) in $2020^{27}$.

Supplying gas to China from Eastern Siberia can be broken down into two options if one leaves aside the specific case of Sakhalin, which is primarily concerned with LNG projects. The first option consists of transporting the gas from the Kovytka deposit, located in Irkutsk Region, to China either via Mongolia or directly through North-Eastern China. This latter option is more costly but is favoured in China as that country does not wish to depend upon Mongolia. The second option consists of supplying China from the Sakha Republic.

\footnotetext{
${ }^{24}$ That is, from Yamal or more probably from the deposits located near to Urengoy.

${ }^{25}$ Toichi (T.).- « Energy Security in Asia and Japanese Policy ».- IEEJ, july 2003, 8 p.

${ }^{26}$ The International Energy Agency gives proven reserves of 3,789 bcm. E. Khartukov proven reserves of 5,300 bcm. Sources: Khartukov E., East Asia's Energy Security: A Russian Perspective, The Journal of Energy and Development, Volume 24 No. 2, 2000, p. 226. AIE/OCDE, 2002, op. cit., p. 227.

${ }^{27}$ This is the energy plan for the 2020 horizon, approved in September 2003 by the Russian Government. The optimistic scenario is based on a hypothetical oil price of $30 \$ /$ barrel in 2020.
} 


\section{- Supplies from Irkutsk}

The feasibility studies are related to the export of $20 \mathrm{bcm}$ per year to China, with a possible further $10 \mathrm{bcm}$ to South Korea. The advantages of this situation are many. In particular, the deposit and the gas pipeline could be developed with assistance from foreign investors, most notably BP. Following the creation of a joint venture with TNK (Tyumen Oil Company), the British giant has become one of the main shareholders in the production company Rusia Petroleum, which holds the development licence for the Kovytka deposit.

There remains the uncertainty concerning the role of Gazprom. Can the gas resources of Eastern Siberia really be developed without this giant Russian gas company being involved at some stage in the development of deposits, infrastructures and exports? Gazprom has made no secret of its wish to take control of gas exports to the Asian markets and to assume the role of co-ordinator in that entire area. Its plans for Eastern Siberia are ambitious. By favouring the domestic market over exports, which will not be made until the period 2014-2020, it has defined objectives that are in contradiction with those publicised by the joint venture TNKBP. For the joint venture, Kovytka will be developed essentially for exports. The Gazprom plan could earn the support of the Russian government, which is anxious to ensure supplies to a region that frequently suffers energy shortages and to maintain a certain control over development of the region's gas resources through the involvement of energy companies in which it is still a majority shareholder ${ }^{28}$. The product sharing agreement negotiations, expected to start following the introduction of the new Russian law on hydrocarbons, may have the effect of lifting the "Gazprom Barrier" by offering it an opportunity to get involved in the development of this deposit ${ }^{29}$.

\section{- Supplies from the Sakha Republic}

The second Russian option consists of transporting gas to China from the deposits in the Sakha Republic, in particular those at Shayandinskoye and Talankan. Less well situated geographically in relation to the anticipated export markets, these deposits would be developed in a second stage, with export projects that may not produce anything concrete until after $2020^{30}$.

\subsection{The Caspian option: the "Energy Silk Route Pipeline".}

This alternative would involve transporting gas from Kazakhstan and Turkmenistan to China and then on to Korea and Japan through transnational pipelines. These countries have a

\footnotetext{
${ }^{28}$ This four-stage development plan envisages the development of Kovytka by 2007, together with the construction of a gas pipeline for supplies to the Irkutsk Region (and not for exports). Then, for the period 20092012, it envisages connecting the Eastern Siberian deposits to the existing gas pipeline network. This period would also see the start of production in the Shayandinskoye Deposit in the Sakha Republic. The first production of deposits in the Krasnoyarsk Region is planned in 2014. Not until the period 2014-2020 would exports begin from the Eastern Siberian deposits.

${ }^{29}$ A preliminary agreement was signed in 2003 between TNK-BP and Gazprom in relation to that company's participation in the Kovytka development project.

${ }^{30}$ « John Roberts considers the rivalry between Siberia and Central Asia ».- Oxford Energy Forum, august 2003, p. $14-17$
} 
number of advantages. The first is the presence of major gas reserves that would allow them to ensure consequent levels of export. According to the sources, these reserves vary between 1,500 and 2,600 bcm for Kazakhstan and between 2,500 and 2,900 bcm for Turkmenistan (cf. Table 2). In consequence, by 2015 Turkmenistan could be able to produce over $100 \mathrm{bcm}$ of gas with a level that according to the optimistic scenario could rise as high as $130 \mathrm{bcm}$. As for Kazakhstan, its production could quickly reach $30 \mathrm{bcm}$ by 2010 , rising to over $50 \mathrm{bcm}$ in 2020 (in the optimistic scenario situation) ${ }^{31}$.

Table 2: Estimation of proven gas reserves in Caspian and Central Asian countries (bcm)*

\begin{tabular}{|l|c|c|c|c|}
\hline & Azerbaijan & Kazakhstan & Uzbekistan & Turkmenistan \\
\hline IEA (1998) & $300-800$ & $1,500-2,400$ & $1,600-2,100$ & 2,700 \\
\hline BP (2001) & 850 & 1,840 & 1,870 & 2,860 \\
\hline Cedigaz & & 1,840 & 1,750 & 2,850 \\
\hline $\begin{array}{l}\text { Wood Mackenzie } \\
(\mathbf{2 0 0 2})\end{array}$ & 600 & 2,630 & - & 2,580 \\
\hline
\end{tabular}

* Without Russia et Iran

Sources: Caspian Oil and Gas : the supply potential of Central Asia and Transcaucasia.- IEA, Paris, 1998 ; Natural Gas in the World 2000 Survey.- Cedigaz, december 2000 ; " Des estimations réalistes des réserves de la Caspienne s'imposent peu à peu ».- Pétrostratégies, 20 may 2002, p. 4-5.

The second advantage of this area is that the hydrocarbon reserves are developed under the aegis of international oil companies. These countries, faced with serious economic difficulties caused by the transition, cannot by themselves make the financial commitments needed for rapid, large-scale development of their deposits. In this context, they have since 1992 attempted to set up a legal and legislative framework aimed at attracting international capital. They have also ratified the treaty on the Energy Charter (which Russia has not done), a move that will in theory allow significant protection for international investors ${ }^{32}$. The major product sharing agreements signed in Kazakhstan, most notably those relating to the Kashagan, Karachaganak and Tengiz deposits, bear witness to the success of this policy, which however is appearing more difficult to implement in Turkmenistan. This country is seen as high-risk; this has the effect of considerably delaying the involvement of international oil companies and may lead to a much slower development of its gas production processes than was originally forecast.

Finally, the last element to be borne in mind is the difficulty encountered by these countries in defining credible strategies for export to European markets, and the gas needs of China and India that are likely to modify their export policies in favour Asia and therefore to the detriment of Europe. With this in mind, a number of projects have been examined since 1992. Some relate more specifically to India, while others are centred on China. This is particularly the case with the "Energy Silk Route Pipeline" project, the aim of which is to transport Turkmen gas (mainly from the Dauletabad deposit) to China, South Korea and India. The volumes exported should be in the region of $30 \mathrm{bcm}$, across a distance of over $6,000 \mathrm{~km}$ for

${ }^{31}$ Smith (R.).- « Politics, production levels to determine Caspian area energy export options ».- Oil and Gas Journal, 28 may 2001, p. 33-38; McCutcheon (H.).- « Risk management, financing availability ».- Oil and Gas Journal, 24 july 2000, p. 38-44; Caspian Oil and Gas : the supply potential of Central Asia and Transcaucasia.IEA, Paris, 1998, p. 52.

\footnotetext{
${ }^{32}$ Azerbaijan and Kazakhstan have also signed bilateral treaties with the United States in relation to investments.
} 
China. A second gas pipeline project is being envisaged between Kazakhstan (most notably from the Karachaganak deposit) and China (Shanghai), a distance of 3,370 km. The volumes exported should total $25 \mathrm{bcm}$. The question of profitability is central for these pipelines, in view of the distances to be crossed, especially for the "Energy Silk Route Pipeline". The completion of the "West-East pipeline" has however increased the credibility of supplying from long-distance gas pipelines, as the distances to be covered will be reduced because of the pipeline linking Xinjiang Province with the consumer zones on the East Coast. Gas imports from Central Asia gas may complement the insufficient Chinese production coming from the Tarim Basin ${ }^{33}$.

Despite clear competition between Russia and the Caspian for supplies to China, these two areas complement each other to a significant extent. The political and economic uncertainty concerning the profitability of pipelines over such long distances suggest rather that exports of gas from Central Asia to Asia are a much more long-term project than the supplies from the nearer Russian sources ${ }^{34}$. In the very long term, therefore, they could take over from the Russian exports and even perhaps use the channels set up by Russia, whose ambition may be to create a major transit point for Caspian gas; this may be towards Asia or towards Europe.

\subsection{Competition between LNG import projects}

Faced with the uncertainty over gas demand in China, and in view of the fall in costs along the chain, the LNG option is becoming more and more desirable in the short term. In the major consumption centres two projects, one at Guandong ${ }^{35}$ and one at Fujian, should be developed before the end of the decade (cf. Table 3).

Table 3: The major Chinese LNG projects

\begin{tabular}{|c|c|c|c|}
\hline Projets & Capacity (Mt/year) & Beginning of importation & Potential suppliers \\
\hline \multirow[t]{2}{*}{ Guandong } & $\begin{array}{c}3,0 \\
\left(1^{\text {ere }} \text { phase }\right)\end{array}$ & 2005 & $\begin{array}{c}\text { Australia } \\
\text { North West Shelf }\end{array}$ \\
\hline & $\begin{array}{c}3,0 \\
\left(2^{\text {ème }} \text { phase }\right)\end{array}$ & 2009 & \\
\hline \multirow[t]{2}{*}{ Fujian } & $\begin{array}{c}2,5 \\
\left(1^{\text {ère }} \text { phase }\right)\end{array}$ & 2007 & $\begin{array}{c}\text { Indonesia } \\
\text { Tangguh }\end{array}$ \\
\hline & $\begin{array}{c}2,5 \\
\left(2^{\text {ème }} \text { phase }\right)\end{array}$ & 2011 & \\
\hline East China & $\begin{array}{c}3,0 \\
\left(1^{\text {ère }} \text { phase }\right)\end{array}$ & 2010 & \multirow[t]{2}{*}{ No final decisions } \\
\hline Shangdong & 1,5 & 2010 & \\
\hline
\end{tabular}

Sources : «NWS signs Guangdong LNG and China LNG agreements ».- Gas Briefing International, october 2002, p. 12 ; « CNOOC, BP win the triple in China LNG awards”.- Gas Matters, august 2002, p. 1-4.

\footnotetext{
33 «LNG to remain dominant ».- Petroleum Economist, may 2003, p. 12.

${ }^{34}$ Stern (J.).- « Chapter 6 : Russian and Central Asian Gas Supply For Asia” in Wybrew-Bond (I.), Stern (J.), eds.- Natural Gas in Asia: The Challenges of Growth in China, India, Japan and Korea.- Oxford Institute for Energy Studies, 2002, p.230-276.

${ }^{35}$ The partners in this project are CNOOC (33\%), local gas and electricity companies (31\%), BP (30\%) and two Hong Kong energy companies (6\%). CNOOC and BP win the triple in China LNG awards, Gas Matters, August 2002, p. 2-4.
} 
The countries able to supply China should first of all be the LNG exporters from South-East Asia (Malaysia, Indonesia, Brunei, Australia etc). To these, Russia may be added through the Sakhalin projects (Sakhalin I and Sakhalin II). The terminal at Guandong will thus take on gas from Australia via the North West Shelf, a joint venture consisting in equal parts of Woodside Petroleum, BHP, BP, Chevron Texaco, Japan Australia LNG and Shell ${ }^{36}$. China, anxious to diversify its suppliers, has chosen Indonesia (Tangguh) to supply its second LNG terminal.

Table 4: LNG exports from the Middle East to South-East Asia in 2001 (bcm)

\begin{tabular}{|c|c|c|c|}
\hline & Oman & Qatar & United Arab Emirates \\
\hline South Korea & 5.30 & 6.67 & 0.17 \\
\hline Japan & 0.83 & 8.30 & 6.89 \\
\hline
\end{tabular}

Source : BP Amoco Statistical Review of World Energy, 2002

In view of the production capacities available, and even though South-East Asia may be able to maintain its position as principal supplier to the area, imports from the Middle East (Qatar, Yemen, Iran, etc) may be envisaged, with possible involvement by Chinese companies in the development of some LNG projects. In fact, even if gas pipelines can be envisaged coming from Iran, it is probable that exchanges of gas alone the Middle East - Asia axis could borrow the LNG route during the next fifteen years. Qatar, Oman and the United Arab Emirates already have a presence in this area, with exports of LNG to Japan and South Korea (cf. Table 4). Their reserves and their production capacity are such that they can envisage themselves in a position as major competitors in South-East Asian countries.

\section{Conclusion}

China is currently facing major choices in relation to its supplies and therefore to its energy policies. The emergence of gas as a source of energy is currently the major stake, as it is undoubtedly one means of addressing the environmental problems currently facing the country. However, the rapid emergence of gas in the equation suggests that significant developments will be made in relation to the traditional Chinese energy strategy of selfsufficiency, which relies on a specific system of prices. This price system, today, poses a problem. In this regard, the emergence of natural gas as an energy source in Chine cannot be contemplated without a set of economic reforms.

More generally, the whole issue of natural gas in China is closely linked to the international integration strategies, especially in relation to hydrocarbons, to be developed in that country. These strategies relate to the import policies to be chosen but also to the involvement of international investors in the development of the Chinese gas industry. The place that the State intends to give to its national companies, on the interior market and on the international markets, is a matter of first importance here. In this matter, it is unlikely that China will be satisfied with being merely an importer without looking to internationalise its oil companies, and through that, to invest in productive hydrocarbon zones. The State's wish to become a shareholder in the Russian oil company Slavneft' when that company is privatised in 2003, and to play an active part in the consortium exploiting the Kashagan deposit in Kazakhstan, are indications. The configuration of the Asian hydrocarbon markets could be altered in the long term as a result.

\footnotetext{
${ }^{36}$ Gas Matters, op. cit., p. 3.
} 


\section{Bibliography}

Caspian Oil and Gas : the supply potential of Central Asia and Transcaucasia.- IEA, Paris, 1998, p. 52.

« China faces daunting realities of building gas industry-and markets ».- Gas Matters, january 2003, p. 11-16.

« China’s government Restructuring Plan Adopted ».- People’s Daily, 22 september 2003.

« CNOOC, BP win the triple in China LNG awards ».- Gas Matters, august 2002, p. 2-4.

Developing China's Natural Gas Market : The Energy Policy Challenges.- AIE-OCDE, 2002, p. 368.

« Faith, not Fact, drives China Gas ».- PIW, 4 august 2003, p. 3.

Fuqiang (Y.), Duan (N.), Huan (Z.), Leerne (M.), Martin (N.), Sinton (J.), Zhou (F.), Zhue (C.).- A Review of China's Energy Policy.- Lawrence Berkeley Laboratory Report, LBL-35336, 1995, 77 p.

« Gas suppliers battle for buyers ».- Petroleum Economist, may 2003, p. 10-11.

« Gazprom, Shell, Hong Kong China Gas Co and Stroitransgaz team up for West-East pipeline ».- Gas Briefing International, october 2001, p. 10.

« John Roberts considers the rivalry between Siberia and Central Asia ».- Oxford Energy Forum, august 2003, p. 14-17.

Khartukov (E.).- «East Asia's Energy Security: A Russian Perspective ».- The Journal of Energy and Development, $\mathrm{Vol} 24, \mathrm{n}^{\circ} 2,2000$, p. 226

« LNG to remain dominant ».- Petroleum Economist, may 2003, p. 12.

« Loi Lei Lai looks at future electricity demand in China ».- Oxford Energy Forum, may 2003, p. 7-8.

McCutcheon (H.).- « Risk management, financing availability ».- Oil and Gas Journal, 24 july 2000

« Modernizing China's Oil and Gas Sector : Structure Reform and Regulation ».- Consolidated Joint Report of The World Bank and the Institute of Economic System and Management, 20 november 2000, 51 p.

"NWS signs Guangdong LNG and China LNG agreements".- Gas Briefing International, october 2002, p. 12.

Petroleum Argus, FSU Energy, 16 may 2003, p. I.

« Philip Andrews-Speed tries to divine China’s future energy policy ».- Oxford Energy Forum, may 2003, p. 5-7.

Smith (R.).- « Politics, production levels to determine Caspian area energy export options ».- Oil and Gas Journal, 28 may 2001, p. 33-38.

Statistical Review of World Energy, 2002.- BP/Amoco, 2003.

Toichi (T.).- « Energy Security in Asia and Japanese Policy ».- IEEJ, july 2003, 8 p.

Xiucheng (D.), Logan (J.).- Expanding Natural Gas Use in China.- Advanced International Studies Unit, april 2002 , p. 52.

Wybrew-Bond (I.), Stern (J.), eds.- Natural Gas in Asia : The Challenges of Growth in China, India, Japan and Korea.- Oxford Institute for Energy Studies, 2002, 319 p. 
